\title{
Effects of Exercise Performed at High Altitude on the Chromosomal DNA Damage in Human Peripheral Lymphocytes
}

\section{Yüksek İrtifada Yapılan Egzersizin İnsan Periferal Lenfositlerinde Kromozomal DNA Hasarına Etkisi}

\author{
Neşe Kocakulak Akpınar ${ }^{\circledR}$, Zuhal Hamurcu ${ }^{2}$, Hamiyet Donmez-Altuntas ${ }^{\circledR}$, Gönül Sungur ${ }^{\circledR}$, Feyzullah Koca ${ }^{1 \oplus}$, \\ Bekir Çoksevim ${ }^{4}$ 일 \\ ${ }^{1}$ Department of Sport Science, Faculty of Health Sciences, İzmir Democracy University, İzmir/Turkey. \\ ${ }^{2}$ Medical Faculty, Department of Medical Biology, Betül Ziya Eren Genome and Stem Cell Center, Erciyes University, Kayseri/Turkey. \\ ${ }^{3}$ Faculty of Health Science, Erciyes University, Kayseri/Turkey. \\ ${ }^{4}$ Department of Physiology, Medical Faculty, Erciyes University, Kayseri/Turkey.
}

\section{ABSTRACT}

igh altitude hypoxia and hypoxic exercise may induce oxidative DNA damage.Our study was investigated the effect on the micronucleus (MN) frequency of performed exercise at $1055 \mathrm{~m}$ and at $2500 \mathrm{~m}$. MN frequency is a biomarker of chromosomal damage, genome instability. 10 female and 10 male totally 20 subject were included in the study. They performed exercise 3 hours per day during 5 days at each two location. The peripheral blood samples obtained before exercise and immediately after the exercise at $1055 \mathrm{~m}$ and $2500 \mathrm{~m}$ altitude both first day and fifth day were cultured. The number of MN values was scored in binucleated cells obtained from mitogen-stimulated lymphocytes of subjects. We found that exercise performed at $1055 \mathrm{~m}$ conditions induced MN formation ( $\mathrm{p}<0.001$ ); whereas exercise performed at $2500 \mathrm{~m}$ induced more $\mathrm{MN}$ formation in human lymphocytes $(p<0.001)$. In addition, in the subjects after ten days came back down to $1055 \mathrm{~m}$ from the mountain MN frequencies was decreased that those of at the end of the five day at $2500 \mathrm{~m}$ altitude $(p<0.001)$. Also, this MN frequency was similar to with basal MN frequency at $1055 \mathrm{~m}$ ( $p>0.05$ ).Our results indicated that exercise and altitude may cause chromosomal DNA damage and may be closely relative to mutagenic effects.

Key Words

Exercise, Micronucleus, High altitude, DNA damage.

\section{öz}

Uüksek irtifa hipoksi ve hipoksik egzersiz oksidatif DNA hasarına neden olabilir. Çalışmamız 1055m ve 2500m'de yapılan egzersizin mikronükleus (MN) sıklığı üzerindeki etkisi araştırıldı. MN frekansı, kromozomal hasarın, genom kararsızlığının bir biyolojik işaretidir 10 erkek, 10 kadın toplam 20 sağlıklı denek çalışmaya dahil edildi. Her iki yerde 5 gün boyunca günde 3 saat egzersiz yaptılar. Egzersizden önce ve egzersizden hemen sonra 1055 m ve 2500 m yükseklikte periferik kan örnekleri hem birinci hem de beşinci günde kültürlendi. Hastaların mitojenle uyarılmış lenfositlerinden elde edilen çift çekirdekli hücrelerde MN değerlerinin sayısı kaydedildi. 1055m koşullarında yapılan egzersizin MN oluşumunu indüklediğini bulduk ( $\mathrm{<}<0.001$ ); 2500 m'de yapılan egzersiz, insan lenfositlerinde daha fazla MN oluşumuna neden olmuştur ( $p<0.001$ ). Ayrıca, on gün sonra dağdan 1055 m’ye geri inen deneklerin MN frekansları, beş günün sonunda $2500 \mathrm{~m}$ rakımdakinden daha düşüktü ( $p<0.001$ ). Ayrıca, bu MN frekansı, 1055 m'deki bazal MN frekansına benzerdi ( $p>0.05)$. Sonuçlarımız egzersiz ve rakımın kromozomal DNA hasarına neden olabileceğini ve mutajenik etkilere yakından görülebileceğini göstermiştir.

\section{Anahtar Kelimeler}

Egzersiz, Mikronükleus, Yüksek irtifa, DNA hasarı. 


\section{INTRODUCTION}

ntense and tiring sports like mountain climbing and nature sports have important systemic and acute local effects on humans [1, 2]. The energy demand during physical exercise causes an increased oxygen uptake, which may increase the production of reactive oxygen species (ROS) [3]. At high altitude we expected lower production of reactive oxygen derivatives due to lack of oxygen and low oxygen demand. However, high altitude exposure leads to altered activity of ROS, which in turn leads to oxidative damage [4-8]. Although ROS has an important role in regulating normal physical activities such as muscle contraction, a dramatic increase in their concentration may damage normal cell function, biomolecules (proteins and lipids) and cellular DNA [9-11].

Previous studies have used a variety of experimental approaches to measure DNA damage, such as comet assay, 8-hydroxy-deoxyguanosine (8-OHdG), micronucleus test $(\mathrm{MN})$, and chromosomal aberration [12-14]. Among these, the MN test has been widely used as a biomarker of chromosomal damage or genome instability in human peripheral blood lymphocytes [12, 14]. $\mathrm{MN}$ originates from either lagging whole chromosomes or acentric chromosome fragments. These genome damage events can be measured with the cytokinesisblock micronucleus (CBMN) assay. The CBMN assay was developed to score MN specifically in cells that completed nuclear division by blocking them at the binucleated stage prior to cytokinesis $[14,15]$.

The effects of exposure hypoxia and high altitude associated hypoxic exercise in humans have been investigated for years [16-21]. These studies investigated the influence of altitude on the generation of oxidative DNA damage [7, 21-24]. However, there is no study regarding the effects on MN frequency/chromosomal DNA damage of exercise performed at high altitudes. Therefore, the aim of this study was to evaluate the influence of high altitudes and exercise on micronucleus frequency.

\section{MATERIALS and METHODS}

Subjects:Study group was formed with students of Erciyes University Collage of Physical Education and Sports. Students were within similar age and fitness ranges, mean age $23.35 \pm 1.66$ year, mean height $168.20 \pm 7.32$ $\mathrm{cm}$, mean body mass $60.05 \pm 8.76 \mathrm{~kg}$, body mass index $21.12 \pm 2.17 \mathrm{~kg} / \mathrm{m} 2$ (mean \pm SD), 10 female and 10 male totally 20 students were included in the study. There were no significant differences between their ages and physical condition. They live at $1055 \mathrm{~m}$ altitude above sea level. All subjects had not experienced high altitude conditions within a period of at least 6 months.

Informed consent was obtained from all subjects before the study. The study protocol and the procedures were approved by the local ethical committee (No; 09/54). The study was conducted in accordance with the Declaration of Helsinki or local laws depending on whichever afforded greater protection for the subjects.

\section{Experimental protocols}

Test protocols were performed on two locations: at 1055 meters studies were applied on the Erciyes University campus which is located at the skirts of Erciyes Mountain (3917 m above sea level), Turkey/Kayseri. 2500 $\mathrm{m}$ high altitude studies were performed at the Erciyes ski-centre on the Erciyes Mountain.

2500 meters studies; The subjects arrived after an hour by bus due to the fact that the centre is $25 \mathrm{~km}$ away from the campus of Erciyes Mountain. Experiments were started after two hours. They did basic interval ski exercises at $2500 \mathrm{~m}$. Their heart rhythm was kept between 140-160 beats/minute and they exercised on skis for 3 hours per day during 5 days. All students stayed at $2200 \mathrm{~m}$ altitude at Erciyes Mountain during the 5 days. Experiments were made in between February 4-8.

1055 meters studies; the students came back down to $1055 \mathrm{~m}$ from the mountain after two weeks (February 25-29) began to work again. All the students performed the same exercises at $1055 \mathrm{~m}$ as they had at $2500 \mathrm{~m}$. They performed exercise for 3 hours per day during 5 days. Their heart rhythms were kept between 140-160 beats/minute during exercise.

1st day and 5th day oxygen saturation, systolic and diastolic blood pressures, heart rate and $\mathrm{MN}$ frequencies were measured before exercise and immediately after exercise at the two locations.

\section{Whole-blood cultures of human lymphocytes}

Three milliliters of heparinised peripheral blood samples were obtained before exercise and immediately after exercise at $1055 \mathrm{~m}$ and $2500 \mathrm{~m}$ altitudes on both first day and fifth day, in addition to, the students came back down to $1055 \mathrm{~m}$ from the mountain, and blood 
samples of them were taken while resting after ten days (February 19).

Approximately $0.4 \mathrm{~mL}$ of heparinised whole blood samples were cultured for 72 hours at $37^{\circ} \mathrm{C}$ in $5 \mathrm{~mL}$ of peripheral blood karyotyping medium that was supplemented with 1.5\% PHA-M to stimulate T-lymphocytes (all sourced from Biological Industries, Kibbutz Beit Haemek, Israel). To determine intra-individual differences, duplicate cultures were prepared for each sample at the specified time.

\section{CBMN assay}

At forty-four hours after the initiation of cultures, cells were blocked from entering cytokinesis by the addition of cytochalasin-B to each culture tube (Sigma-Aldrich, St Louis, MO; final-concentration, $3 \mu \mathrm{g} / \mathrm{mL}$ ) [14]. The cultures were stopped at 72 hours after initiation, treated with hypotonic solution $(0.1 \mathrm{~mol} / \mathrm{L} \mathrm{KCl})$ for 4 minutes and fixed using 2 changes of methanol-acetic acid (3:1) $[14,25]$. The fixed cells were spread onto glass slides and stained with $5 \%$ Giemsa (Merck) in Sorensen buffer for 10 minutes. To determine the intra-individual differences, the different slides of the 2 parallel cultures for each sample were prepared and evaluated. All slides were scored blindly using light optical microscope. A minimum of 1000 binucleated cells well surrounded by cytoplasm were scored from each sample and the number of binucleated cells with $\mathrm{MN}$ was recorded. Published criteria for $\mathrm{MN}$ determination were followed [26]. The MN frequency (\%) is the ratio of the number of micronuclei to the number of binucleated cells scored.

\section{Statistical analysis}

Differences before exercise and immediately after exercise at each of two locations for subjects were investigated using Wilcoxon Sign Ranks Test for two related samples test. Essentially similar results were obtained by one-way ANOVA. A significant level was set at a Pvalue of $<0.05$

\section{RESULTS and DISCUSSION}

Table 1 shows heart rate, arterial oxygen saturation obtained before exercise and immediately after exercise at $1055 \mathrm{~m}$ and $2500 \mathrm{~m}$ altitude. Data obtained from high altitude associated hypoxia (2500 m) were compared with those obtained from $1055 \mathrm{~m}$. In high altitude associated the first and fifth day maximal heart rate increased $(p<0.05)$, but arterial oxygen saturation decreased $(p<0.05)$.

\section{$\mathrm{MN}$ frequency results at $\mathbf{1 0 5 5} \mathrm{m}$ altitude above sea level}

Mean values of MN frequencies from both the first and the fifth day before exercise, and immediately after exercise are shown in Table 2. The MN frequencies increased at fifth day compared with the first day $(p<0.001$, Table 2). But, no difference was found in MN frequencies between the first and the fifth day before exercise and immediately after exercise ( $p>0.05$, Table 2 ).

Table 1. legend. ${ }^{*} p<0.05$ compared with 1055 metres, $p<0.05$ compared with value at rest.

\begin{tabular}{|l|l|ll|l|}
\hline & \multicolumn{3}{|c|}{ First Day } & \multicolumn{3}{|l|}{ Fifth Day } \\
\cline { 2 - 5 } & $\begin{array}{l}1055 \text { metres } \\
(\mathrm{n}=20)\end{array}$ & $\begin{array}{l}2500 \text { metres } \\
\text { (Altitude } \\
\text { hypoxia) }(\mathrm{n}=20\end{array}$ & $\begin{array}{l}1055 \text { metres } \\
(\mathrm{n}=20)\end{array}$ & $\begin{array}{l}2500 \text { metres } \\
\text { (Altitude } \\
\text { hypoxia) (n=20 }\end{array}$ \\
\hline $\begin{array}{l}\text { Heart rate rest } \\
\text { (beats/min) } \\
\text { (mean } \pm \text { SD }\end{array}$ & $87.05 \pm 13.41$ & $84.15 \pm 7.84$ & $79.40 \pm 9.74$ & $87.70 \pm 7.52^{*}$ \\
\hline $\begin{array}{l}\text { Heart rate max } \\
\text { (beats/min) } \\
\text { (mean } \pm \text { SD }\end{array}$ & $87.15 \pm 16.53$ & $95.55 \pm 7.01^{*}$ & $92.00 \pm 13.75^{*}$ & $101.60 \pm 7.63^{*}$ \\
\hline $\begin{array}{l}\text { Saturation rest } \\
(\%) \\
\text { (mean } \pm \text { SD }\end{array}$ & $96.05 \pm 1.85$ & $95.60 \pm 1.81$ & $97.05 \pm 1.09$ & $94.90 \pm 1.57^{*}$ \\
\hline $\begin{array}{l}\text { Saturation max } \\
(\%) \\
\text { (mean } \pm \text { SD }\end{array}$ & $96.50 \pm 1.15$ & $93.60 \pm 1.90^{*}$ & $96.50 \pm 1.34$ & $94.50 \pm 1.35^{*}$ \\
\hline
\end{tabular}


Table 2. legend. ap<0.001: the means of $M N$ freqencies increased at fifth day compared with their at first day in both at 1055 metres and at 2500 metres. Further, there were differences between found in means of MN frequencies obtained from at 2500 metres compared to their at 1055 metres ( $b p<0.001)$.

\begin{tabular}{|c|c|c|c|c|}
\hline \multirow[b]{2}{*}{$\begin{array}{l}\text { Altitude from sea } \\
\text { level (metres) }\end{array}$} & \multicolumn{2}{|l|}{ First day } & \multicolumn{2}{|l|}{ Fifth day } \\
\hline & $\begin{array}{l}\text { before exercise } \\
M N(\%) \\
(\text { mean } \pm \mathrm{SD})\end{array}$ & $\begin{array}{l}\text { immediately after } \\
\text { exercise } \\
\mathrm{MN}(\%) \\
(\mathrm{mean} \pm \mathrm{SD})\end{array}$ & $\begin{array}{l}\text { before exercise } \\
M N(\%) \\
(\text { mean } \pm \mathrm{SD})\end{array}$ & $\begin{array}{l}\text { immediatel } \\
\text { exercise } \\
\mathrm{MN}(\%) \\
(\text { mean } \pm \text { SL }\end{array}$ \\
\hline 1055 metres $(\mathrm{n}=20)$ & $0.72 \pm 0.30$ & $0.63 \pm 0.28$ & $0.93 \pm 0.31^{\mathrm{a}}$ & $1.05 \pm 0.40$ \\
\hline $\begin{array}{l}2500 \text { metres }(\mathrm{n}=20) \\
\text { (Altitude hypoxia) }\end{array}$ & $0.84 \pm 0.39$ & $0.84 \pm 0.39$ & $2.21 \pm 0.62^{\mathrm{a}, \mathrm{b}}$ & $2.07 \pm 0.60$ \\
\hline
\end{tabular}

\section{MN frequency results high altitude associated} hypoxia (at $\mathbf{2 5 0 0} \mathrm{m}$ altitude above sea level)

MN frequency in both the first and the fifth day before exercise and immediately after exercise are shown in Table 2. No difference was found in MN frequencies obtained on the first and the fifth day before exercise and immediately after exercise ( $p>0.05$, Table 2). However, there was a highly significant increase in means of $\mathrm{MN}$ frequencies at the fifth day when compared to those on the first day $(p<0.001$, Table 2).

\section{Comparison of MN frequency results at $2500 \mathrm{~m}$ and $1055 \mathrm{~m}$}

There were significant differences found in the means of MN frequencies obtained at 2500 meters compared to those at $1055 \mathrm{~m}$ (Table 2). No difference was found between means of MN frequencies from the first day before exercise and immediately after exercise ( $p>0.05)$. Exercise performed at $2500 \mathrm{~m}$ altitude further aggravated the induction of $\mathrm{MN}$ frequencies compared with exercise performed at $1055 \mathrm{~m}$. MN frequencies showed

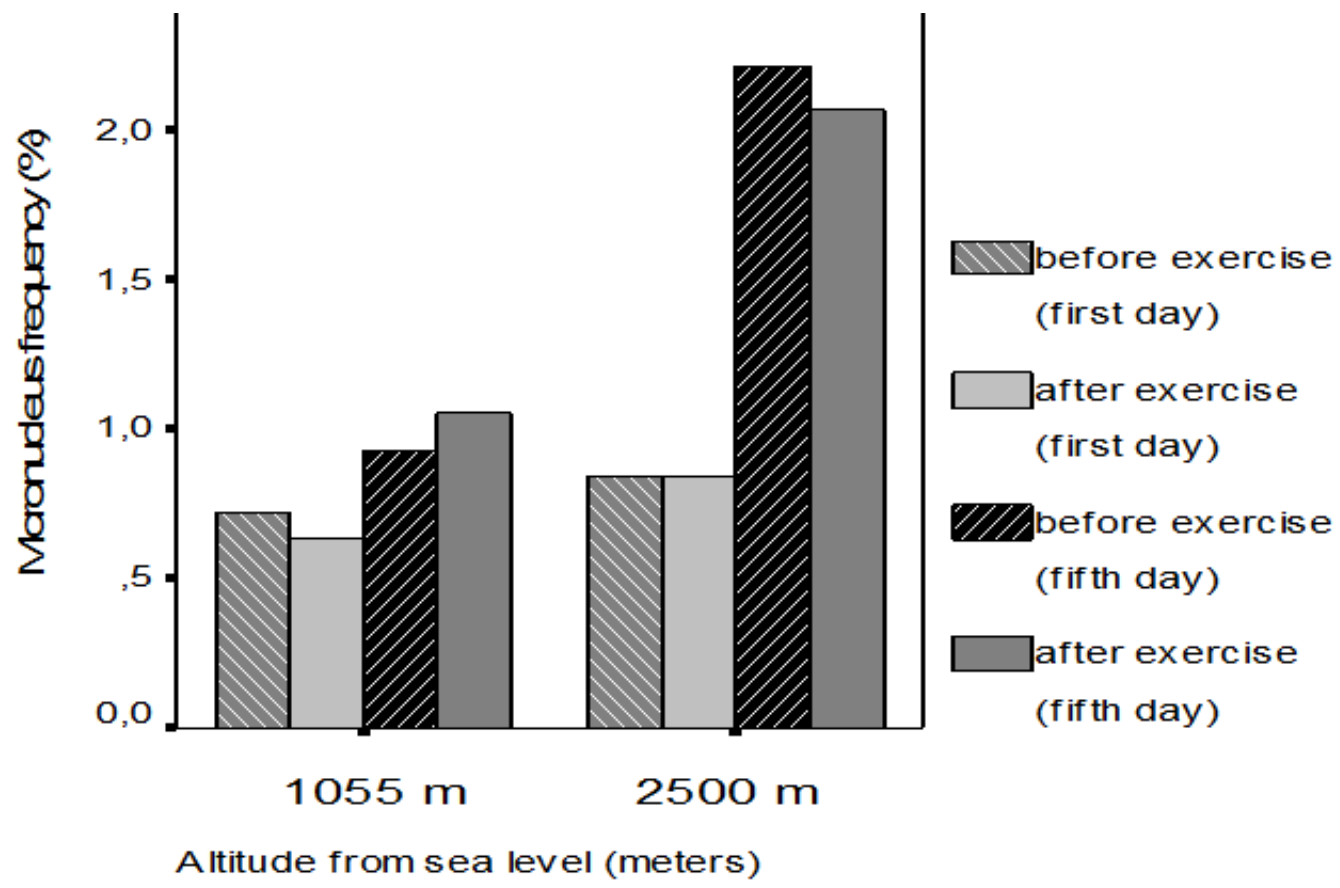

Figure 1. At 2500 metres altitude, exercise further aggravated the induction of MN frequencies compared with those of 1055 metres exercise. 


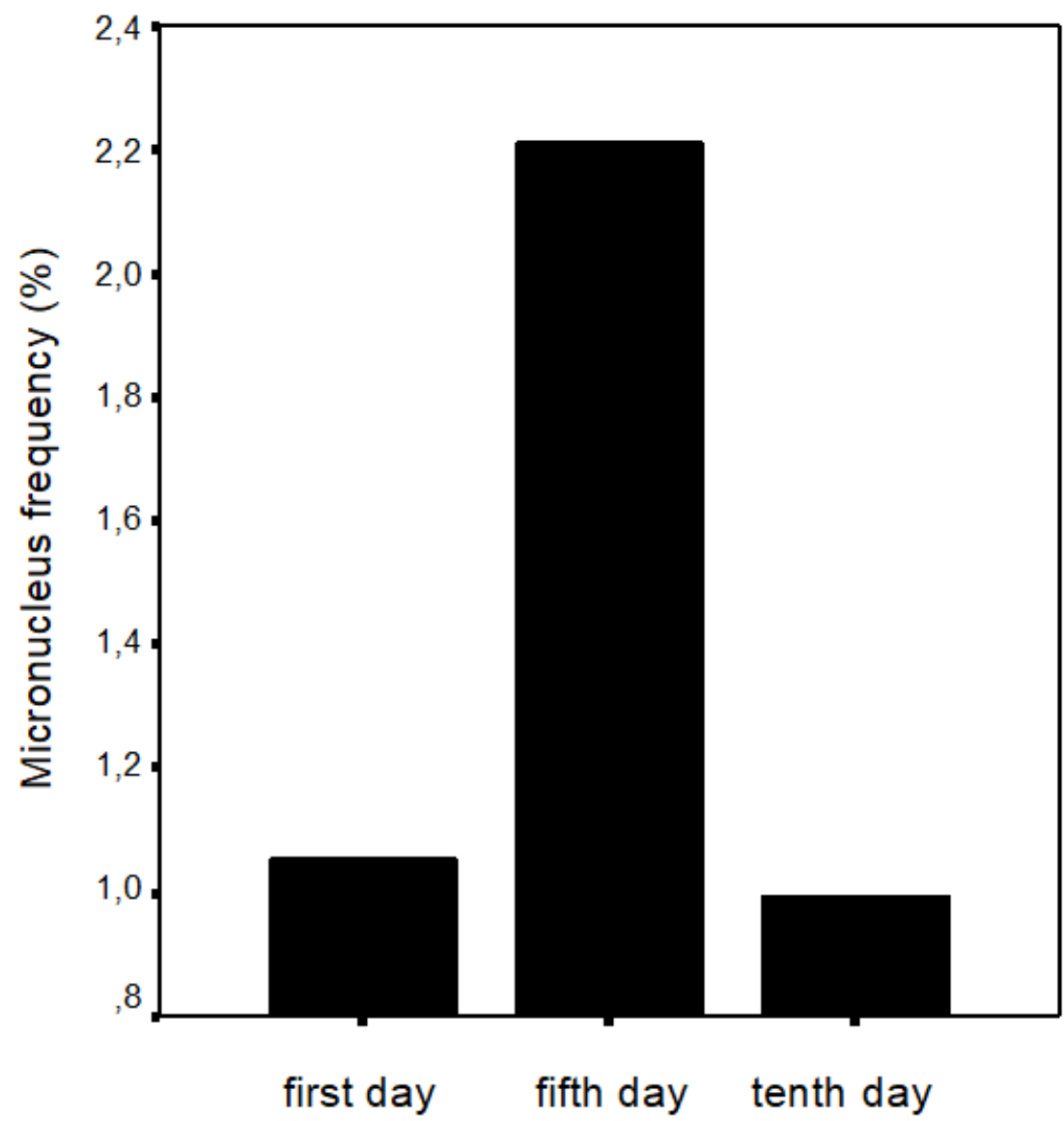

Figure 2. The subjects came back again from $2500 \mathrm{~m}$ to $1055 \mathrm{~m}$ at the end of fifth day. In the subjects, on the tenth day after they return, the number of micronucleus were found in basal level. High MN frequencies obtained at the end of the fifth day at $2500 \mathrm{~m}$ was found to be in basal level at the end of the tenth day at $1055 \mathrm{~m}(p=0.000)$, and it equalized with the same level of MN frequency obtained one day before the exercise started $(p=0.202)$.

a significant increase after 5 days exercise at $2500 \mathrm{~m}$ ( hypoxia altitude ) compared to those after 5 days exercise at $1055 \mathrm{~m}(\mathrm{p}<0.001$,$) .$

In addition, a significant decrease in $\mathrm{MN}$ frequencies obtained at the end of the five days at $2500 \mathrm{~m}$ altitude was seen ten days after the students came back down $1055 \mathrm{~m}$ from the mountain $(\mathrm{p}<0.001)$. Also, this MN frequency value was similar to the basal MN values at 1055 $m(p>0.05)$.

researchers generally agree that exercise increases the production of ROS and consequently leads to damage to DNA in the cell [27-31].

The CBMN assay is one of the preferred methods to detect and measure DNA damage and chromosomal instability phenotype in mammalian and human cells. This study examined effects on MN frequency of the expo- sure to two independent inducers (exercise and altitude). In the present study, we found that MN frequency increased after exercise performed at both $2500 \mathrm{~m}$ and $1055 \mathrm{~m}$. In addition, MN frequency at $2500 \mathrm{~m}$ altitude was found to be higher than that at $1055 \mathrm{~m}$ altitude. This is the first report to show increased MN frequency in peripheral lymphocytes of both exercise and altitude. It is possible to find many studies on the association between high altitude and oxidative stress, and some of these studies reported that high altitude exposure causes oxidative DNA damage $[2 ; 7,8,20]$. In addition, Moller et al. [18] reported that acute hypoxia and hypoxic exercise induce DNA strand breaks and oxidative DNA damage in humans. DNA damage may turn into chromosome alterations that are detected by the MN assay. $\mathrm{MN}$ can originate from lagging acentric chromosome or chromatid fragments formed by misrepair of DNA breaks or unrepaired DNA breaks during anaphase [15]. To our knowledge, there is no study examining the effects 
on $\mathrm{MN}$ frequency of exercise performed at altitude. In this study we tested whether or not exercise performed at high altitude induced MN formation. We found that exercise performed at high altitude $(2500 \mathrm{~m})$ revealed more increased MN frequency compared with MN frequency obtained at lower altitude (1055m). According to our results, it seems that high altitude hypoxia exposure may also lead to chromosomal DNA damage in humans.

It is reported that altitudes can be divided into low altitude $(<2,500 \mathrm{~m})$, high altitude $(2,500 \mathrm{~m}-3,500 \mathrm{~m})$, very high altitude $(3,500 \mathrm{~m}-5,800 \mathrm{~m})$, and extreme altitude (>5,800 m) (Moller et al., 2008).We limited the studies into two classes of altitude (1055 m and $2500 \mathrm{~m}$ ). In our study we found that exposure to high altitude is associated with higher MN frequency. It is well known that UV radiation is significantly increased at high altitude. UV radiation gives rise to DNA damage in mammalian cells. Nair-Shalliker et al. [32] showed that the MN frequency increased with increasing sun ray exposure. Also, exercise performed with high altitude associated hypoxia very often results in oxidative damage $[18,33]$. Besides, it has been shown to increase oxidative stress at high altitude even without exercise Jefferson et al. [2]. On the other hand, as is well known, ultraviolet rays (UV), by generating abundant ROS and free radicals, lead to damage of cells and tissue. According to our results, exercise performed at low altitude $(1055 \mathrm{~m})$ conditions induced MN formation; whereas exercise performed at high altitude associated hypoxia induced more MN formation in human lymphocytes. This may be due to different factors at high altitude such as UV, low oxygen pressure, cold and increased energy demand. It is reported that factors such as UV, sunlight induces/ increases $M N$ formation $[32,34]$. So, we think that at high altitude conditions such as UV, cold and low oxygen levels, in addition to exercise, may contribute to the higher MN frequency.

In humans, the available studies submit that immediately after exercise the level of oxidative damage to DNA is unchanged, but DNA damage may appear hours after exercise $[15 ; 35,36]$. In our study, at both altitudes we found no difference in $\mathrm{MN}$ frequency between before exercise and immediately after exercise. We think that neither exercise nor altitude is sufficiently strenuous to cause significant effects on DNA damage immediately after exercise.
There are studies on the association between exposure hypoxia and hypoxic exercise and oxidative DNA damage in samples obtained from humans and animals. Studies of exercise performed at altitudes between1650$4559 \mathrm{~m}$ above sea level found increases in oxidative DNA damage levels and DNA strand breaks in humans by comet assay [1, 18, 23, 37]. In our study we found increasing $\mathrm{MN}$ frequency of exercise performed at both $1055 \mathrm{~m}$ and $2500 \mathrm{~m}$ altitudes. Although in general the comet assay and MN test may be considered as a more sensitive method to assess DNA damage, different mechanisms are involved [38]. While the comet assay is used as a method for DNA strand break detection, the $\mathrm{MN}$ test is used to detect structural and/or numerical chromosome aberrations by indirect DNA damage [38]. According to our results both exercise and high altitude induced MN formation. It seems to us that exercise and altitude may be closely relative to mutagenic effects, and may cause chromosomal DNA damage.

Oxidative DNA damage has been widely investigated in exercise hypoxia, hypoxic exercise [7, 8] and exercise [31, 39]. However, literature data are controversial. Ohkuwa et al. [40] have shown that hypoxia and hypoxic training result in decreased oxidative DNA damage in the livers of rats. Moller et al. [18] have found that hypoxia and hypoxic exercise result in increased DNA strand breaks and oxidative DNA damage. These differences may depend on high altitude associated hypoxia exposure time and exercise type. In contrast, data on MN frequency in exercise studies are limited, and six studies have reported on the effects of exercise on MN frequency in human peripheral blood lymphocytes in recent review by Fenech and Bonassi [41]. Some investigators observed an increase in MN frequency after exercise [42], while others reported no change $[43,44]$ or decrease before and at various times after exercise [45]. We found no change in $\mathrm{MN}$ frequency immediately after exercise, whereas $\mathrm{MN}$ frequencies increased at fifth day compared with the first day. These contradictory results may be accounted for by the degree, period and exercise type, and training status of individuals.

MN assay demonstrates damage at the chromosomal level leading to more severe genome instability, and the presence of micronucleus in the cell represents irreparable genomic instability. The maintenance of genomic stability is one of the most important defenses against transformation. So, cells respond to DNA damage by 
two mechanisms: DNA repair or apoptosis. The process removes cells with damaged DNA from the pool of replicating cells, avoiding the introduction of mutations into the genome and associated risk of cancer [46]. Subjects returned from $2500 \mathrm{~m}$ to1055 $\mathrm{m}$ at the end of five days. In the subjects, 10 days after returning MN frequency was evaluated again, and 10 days after the number of micronucleus found in basal level. We think that the cells with micronucleus may be eliminated by apoptosis for maintenance of genomic stability of cells.

Increased MN frequencies have been shown to be predictive for cancer and are considered valuable biomarkers for early genetic effects [47]. The presence of an association between the frequency of MN in lymphocytes and pathology of carcinogenesis, neurodegenerative, diabetes and cardiovascular disease has been supported by a number of findings [47-50].

Our study show that increased MN frequency in peripheral lymphocytes of both exercise and altitude. It is may lead an increase risk of cancerogenesis, metabolic syndrome and cardiovascular disease.

We concluded that both exercise and high altitude associated exercise may cause mutations at the DNA/chromosomal level in human peripheral lymphocytes; moreover it may increases the sensitivity of an individual's cells to normal genotoxic stresses. However, more detailed studies are needed on exercise and altitude induced mutagenic effects.

\section{Acknowledgement}

This research was supported by Erciyes University Scientific Research Projects Units (Project number: TSY09-712, Z. HAMURCU).

\section{References}

1. P.Moller, Genotoxicity of environmental agents assessed by the alkaline comet assay, Basic Clin Pharmacol Toxicol., 1 (2005) 1-42.

2. J.A. Jefferson, J.Simoni, E. Escudero, M.E. Hurtado , E.R. Swenson, D.E. Wesson, G.F. Schreiner, R.B. Schoene, R.J. Johnson, A. Hurtado, Increased oxidative stres following acute and chronic high altitude exposure, High Altitude Med Biol., 5 (2004) 61-9.
3. G.W. Davison, Exercise and Oxidative Damage in Nucleoid DNA Quantified Using Single Cell Gel Electrophoresis: Present and Future Application, Front Physiol., 7 (2016) 249.

4. H. Kumar, D.K. Choi, Hypoxia Inducible Factor Pathway and Physiological Adaptation: A Cell Survival Pathway? Mediators Inflamm., (2015) 584758

5. G. Alkorta-Aranburu, C.M. Beall, D.B. Witonsky, A. Gebremedhin, J.K. Pritchard, A. Di Rienzo, The genetic architecture of adaptations to high altitude in Ethiopia, PLoS Genet., 8 (2012) 1003.

6. E.W. Askew, Work at high altitude and oxidative stress: antioxidant nutrients, Toxicol., 180 (2002) 107-119.

7. P. Møller, L. Risom, C. Lundby, L. Mikkelsen, S. Loft, Hypoxia and oxidation levels of DNA and lipids in humans and animal experimental models, IUBMB Life., 60 (2008) 707-23.

8. A. Dosek, H. Ohno, Z. Acs, A.W. Taylor, Z. Radak, High altitude and oxidative stress, Respir Physiol Neurobiol., 158 (2007) 128-131.

9. Z. Radak, K. Suzuki, M. Higuchi, L. Balogh, I. Boldogh, E. Koltai, Physical exercise, reactive oxygen species and neuroprotection, Free Radic Biol Med., 98 (2016)187-196.

10. R.J. Bloomer, A.H. Goldfarb, L. Wideman, M.J. McKenzie, L.A. Consitt, Effects of acute aerobic and anaerobic exercise on blood markers of oxidative stress, J. Strength. Cond. Res., 19 (2005) 276-85.

11. R.J. Bloomer, A.H. Goldfarb, J.M. Mckenzie, Oxidative stress response to aerobic exercise: Comparison of antioxidant supplements, Med Sci Sports Exerc., 38 (2006) 1098-105.

12. Z. Hamurcu, F. Bayram, G. Kahriman, H. Dönmez-Altuntas, G. Baskol, Micronucleus frequency in lymphocytes and 8-hydroxydeoxyguanosine level in plasma of women with polycystic ovary syndrome, Gynecol Endocrinol., 26 (2010) 590-5.

13. R.P. Araldi, T.C. de Melo, T.B. Mendes, P.L. de Sá Júnior, B.H. Nozima, E.T. Ito, R.F. de Carvalho, E.B. de Souza, R. de Cassia Stocco, Using the comet and micronucleus assays for genotoxicity studies: A review, Biomed. Pharmacother., 72 (2015) 74-82.

14. M. Kirsch-Volders, S. Bonassi, S. Knasmueller, N. Holland, C. Bolognesi, M.F. Fenech, Commentary: critical questions, misconceptions and a road map for improving the use of the lymphocyte cytokinesis-block micronucleus assay for in vivo biomonitoring of human exposure to genotoxic chemicals-a HUMN project perspective, Mutat. Res. Rev .Mutat Res., 759 (2014) 49-58.

15. M. Fenech, The micronucleus assay determination of chromosomal level DNA damage, Method. Mol. Biol., 410 (2008) 185-216.

16. M. Fenech, M. Kirsch-Volders, A.T. Natarajan, J. Surralles, J.W. Crott, J. Parry, H. Norppa, D.A. Eastmond, J.D. Tucker, P. Thomas, Molecular mechanisms of micronucleus, nucleoplasmic bridge and nuclear bud formation in mammalian and human cells, Mutagenesis., 26 (2011) 12532.

17. A. Wozniak, G. Drewa, G. Chesy, A. Rakowski, M. Rozwodowska, D. Olszewska, Effect of altitude training on the peroxidation and antioxidant enzymes in sportsmen, Med. Sci. Sport. Exer., 33 (2001) 1109-13.

18. P. Møller, S. Loft, C. Lundby, N.V. Olsen, Acute hypoxia and hypoxic exercise induce DNA strand breaks and oxidative DNA damage in humans, FASEB J., 15 (2001) 1181-6. 
19. V. Pialoux, R. Mounier, E. Rock, A. Mazur, L. Schmitt, J.P. Richalet, P. Robach, J. Brugniaux, J. Coudert, N. Fellmann, Effects of the 'live high-train low' method on prooxidant/ antioxidant balance on elite athletes, Eur. J. Clin. Nutr., 63 (2009) 756-762.

20. S. Sinha, A. Dutta, S.A. Singh, U.S. Ray, Protein nitration, lipid peroxidation and DNA damage at high altitude in acclimatized lowlanders and native highlanders: relation with oxygen consumption, Respir. Physiol. Neurobiol., 171 (2010) 115-21

21. T.J. Vasankari, U.M. Kujala, H. Rusko, S. Sarna, M. Ahotupa, The effect of endurance exercise at moderate altitude on serum lipid peroxidation and antioxidative functions in humans, Eur. J. Appl. Physiol., 75 (1997) 396-399.

22. W. H. Chao, E.W. Askew, D.E. Roberts, S.M. Wood, J.B. Perkins, Oxidative stress in humans during work at moderate altitude, J. Nutr., 129 (1999) 2009-11.

23. J.M. Pfeiffer, E.W.Askew, D.E. Roberts, S.M. Wood, J.E. Benson, S.C. Johnson, M.S. Freedman, Effect of antioxidant supplementation on urine and blood markers of oxidative stress during extended moderate-altitude training, Wilderness Environ. Med., 10(1999) 66-74.

24. J. Magalhães, A. Ascensão, G. Viscor, J. Soares, J. Oliveira, F. Marques, J. Duarte, Oxidative stress in humans during and after 4 hours of hypoxia at a simulated altitude of $5500 \mathrm{~m}$ Aviat. Space. Environ. Med., 75 (2004)16-22.

25. Z. Hamurcu, H. Dönmez-Altuntas, T. Patiroglu, Basal level micronucleus frequency in stimulated lymphocytes of untreated patients with leukemia, Cancer Genet. Cytogenet. 180 (2008) 140-4.

26. M.Fenech, Cytokinesis-block micronucleus cytome assay, Nat. Protoc., 2 (2007) 1084-104.

27. B. Tomasello, S. Grasso, G. Malfa, S. Stella, M. Favetta, M. Renis, Double-face activity of resveratrol in voluntary runners: assessment of DNA damage by comet assay, J. Med. Food., 15 (2012) 441-447.

28. K.H. Wagner, S. Reichhold, O. Neubauer, Impact of endurance and ultra endurance exercise on DNA damage, Ann. NY Acad. Sci., 1229 (2011) 115-23.

29. M.C. Fogarty, C.M. Hughes, G. Burke, J.C. Brown, T.R.Trinick, E. Duly, D.M Bailey, G.W. Davison, Exercise-induced lipid peroxidation: Implications for deoxyribonucleic acid damage and systemic free radical generation, Environ. Mol. Mutagen., 52 (2011) 35-42.

30. G. Gandhi, G. Chopra, DNA damage in peripheral blood leukocytes of physically active individuals as measured by the alkaline single cell gel electrophoresis assay, Environ. Mol. Mutagen., 50 (2009) 291-303.

31. Z. Radak, J. Pucsuk, S. Boros, L. Josfai, A.W. Taylor, Changes in urine 8-hydroxydeoxyguanozine levels of super marathon runners during a four-day race period, Life Sci., 66 (2000) 1763-1767.

32. V. Nair-Shalliker, M. Fenech, P.M. Forder, M.S. Clements, B.K. Armstrong, Sunlight and vitamin D affect DNA damage, cell division and cell death in human lymphocytes: a crosssectional study in South Australia, Mutagen., 27 (2012) 609 14.

33. Z. Radak, Z. Zhao, E. Koltai, H. Ohno, M. Atalay, Oxygen consumption and usage during physical exercise: the balance between oxidative stress and ROS-dependent adaptive signaling, Antioxid. Redox. Signal., 18 (2013) 1208 46.
34. Z. Hamurcu, H. Demirtas, O. Ascioglu, H. Dönmez-Altuntas, E. Aktas, Micronucleus evaluation in mitogen-stimulated lymphocytes of PUVA treated patients, Tohoku J. Exp. Med., 198 (2002) 11-21.

35. Z. Hamurcu, N. Saritas, G. Baskol, N. Akpinar, Effect of wrestling exercise on oxidative DNA damage, nitric oxide level and paraoxonase activity in adolescent boys, Pediatr. Exerc. Sci., 22 (2010) 60-68.

36. H.E.Poulsen, A.Weimann, S. Loft, Methods to detect DNA damage by free radicals: relation to exercise, Proc. Nutr. Soc., 58 (1999) 1007-1014.

37. C. Lundby, H. Pilegaard, G.Van Hall, M. Sander, J. Calbet, S. Loft, P. Møller, Oxidative DNA damage and repair in skeletal muscle of humans exposed to high-altitude hypoxia, Toxicol., 192 (2003) 229-36.

38. S.W.Maluf, Monitoring DNA damage following radiation exposure using cytokinesis-block micronucleus method and alkaline single-cell gel electrophoresis, Clin. Chim. Acta., 347 (2004) 15-24.

39. S.K.Powers, W.B Nelson, M.B. Hudson, Exercise-induced oxidative stress in humans: cause and consequences, Free Radic. Biol. Med., 51 (2011) 942-50.

40. T. Ohkuwa, H. Itoh, T. Yamamoto, C. Minami, Y. Yamazaki, S. Kimoto, R. Yoshida, Effects of hypoxia and hypoxic training on 8-hydroxydeoxyguanosine and glutathione levels in the liver, Metabolism., 53 (2004) 716-719.

41. C. Schiffl, C. Zieres, H. Zankl, Exhaustive physical exercise increases frequency of micronuclei, Mutat. Res., 389 (1997) 243-246.

42. M.Fenech, S. Bonassi, The effect of age, gender, diet and lifestyle on DNA damage measured using micronucleus frequency in human peripheral blood lymphocytes, Mutagen., 26 (2011) 43-9.

43. A. Hartmann, S. Pfuhler, C. Dennog, D. Germadnik, A. Pilger, G. Speit, Exercise-induced DNA effects in human leukocytes are not accompanied by increased formation of 8-hydroxy2 '-deoxyguanosine or induction of micronuclei, Free Radic. Biol. Med., 24 (1998) 245-251.

44. K.Umegaki, M. Higuchi, K. Inoue, T. Esashi, Influence of one bout of intensive running on lymphocyte micronucleus frequencies in endurance-trained and untrained men, Int. J. Sports Med., 19 (1998) 581-585.

45. S. Reichhold, O. Neubauer, V. Ehrlich, S. Knasmüller, K.H.Wagner, No acute and persistent DNA damage after an Ironman triathlon, Cancer Epidemiol. Biomark. Prev., 17 (2008) 1913-1919.

46. S. Meintières, A. Biola, M. Pallardy, D. Marzin, Apoptosis can be a confusing factor in in vitro clastogenic assays, Mutagen., 16 (2001) 243-50.

47. N. Holland, A. Fucic, D.F. Merlo, R. Sram, M. KirschVolders, Micronuclei in neonates and children: effects of environmental, genetic, demographic and disease variables, Mutagen., 26 (2011) 51-56.

48. M.G.Andreassi, R. Barale, P. Iozzo, E. Picano, The association of micronucleus frequency with obesity, diabetes and cardiovascular disease, Mutagen., 26 (2011) 77-83.

49. M. Fenech, The Genome Health Clinic and Genome Health Nutrigenomics concepts: diagnosis and nutritional treatment of genome and epigenome damage on an individual basis, Mutagen., 20 (2005) 255-69.

50. L.Migliore, F. Coppedè, M. Fenech, P. Thomas P, Association of micronucleus frequency with neurodegenerative diseases, Mutagen., 26 (2011) 85-92. 